\title{
Obstacles of Accessibility for the Diffabled People in the Campus 1 UPGRIS
}

\author{
Baju Arie Wibawa*, Kurnia Widiastuti \\ Universitas Persatuan Guru Republik Indonesia Semarang, Indonesia \\ *Corresponding e-mail: bayu.ariwibawa@gmail.com
}

Article info:

Received: 10-10-2018, Revised: 24-10-2018, 04-12-2018, Accepted: 11-12-2018

\begin{abstract}
As a public building, the Campus 1 of UPGRIS requires to comply with the accessibility for all (including the diffabled people). Yet, the current condition causes the diffable people unable to access the facilities of the building, which means they are not capable of doing their activities on their own. How should we determine the condition? and how should be advise to retrofit?. The purpose of this reasearch is to identify and analyse the need of diffabled people facilities in campus 1 UPGRIS which have multiple factor. Qualitative and quantitative methods are used in the process of analyzing the problem through comparative analysis according to the regulation, hereinafter a scoring analysis will be held quantitatively to determine the priority of the problem. Commonly the dimension of the doors which width less than $80 \mathrm{~cm}$, so the wheelchair can't go through the room. The conclusion for all building, is not prepared well for the diffable people acting independently.
\end{abstract}

Keywords: accessibility, disability, diffabled people, public services

\section{Introduction}

The Campus 1 UPGRIS as one of the public buildings that serve many students has a public service function, therefore the building has to meet the requirements for certain space for everyone, including for diffabled people (Harahap \& Bustanuddin, 2015). The existing buildings have served to diffable, so they have not been able to do their activities independently as mandated by the law. The Law for diffabled people has guaranteed (Masruroh, Mauliani, Ayodia, \& Menteng, 2006; Utomo, 2014), and the technical regulation has been prepared by the Minister of Public Works and Settlement but its implementation is still very rare. There are several barriers that are still faced: unavailability of ramp, lack of pedestrians and guide block, uneven road surfaces, the door widths are too narrow, slippery floors, unavailability of parking for diffable, no elevators, no sanitation facilities, stairs that have no safety fences, etc (Tarsidi, 2008).

The demand for the provision of public service facilities that are friendly for persons with disabilities is also included in the pedestrian networks on UPGRIS Campus 1 Semarang. The existing conditions in several existing buildings are not designed from the accessibility aspect of the building, according

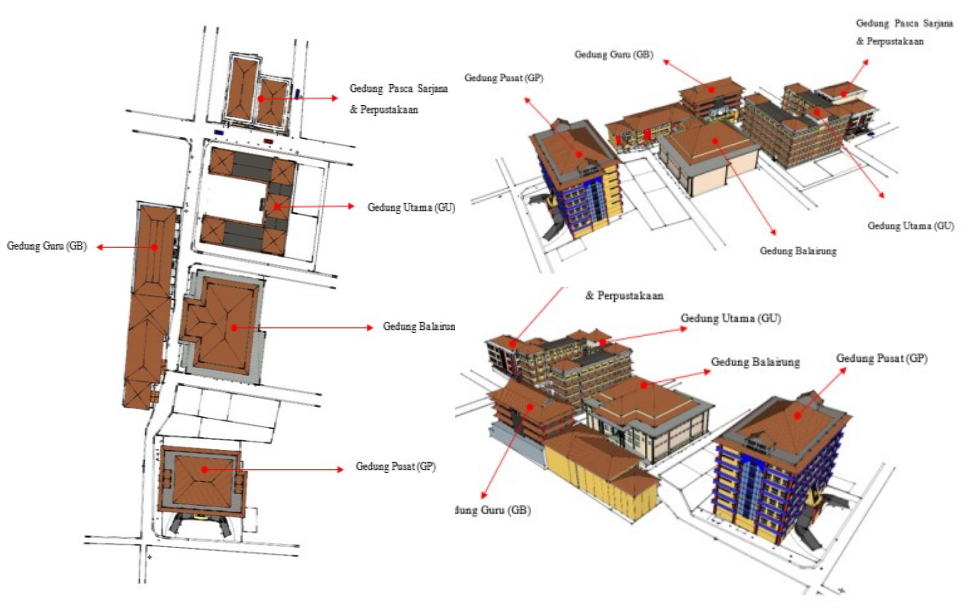

Figure 1. The building as research object (Analysis, 2018) 
to this, there are various obstacles in the field. These various problems are expected to be correctly identified and analyzed therefore, they can be handled priority improvements. The problem in this study is "how are the obstacles of the building accessibility on UPGRIS campus 1 to complete the rights of diffabled people?"

\section{Methods}

The methods of the research are mixing either of qualitative nor quantitative analyze. The research methodology uses a qualitative-rationalistic approach with descriptive analysis. Excavation of data through direct observation of objects that become research cases and cross interviews with related informants. Research variables include door, corridor, stairs, ramps, lift, toilet, handwashing, urinal and parking lot. The selection of buildings are(see Figure 1):

- Central Building-GP (Gedung Pusat)

- Balairung Building (Balairung)

- Main Building-GU (Gedung Utama)

- Teacher Building-GB (Gedung Guru)

- Magister and Library Building-GPs (Magister \& Library Building)

\section{Result \& Discussion}

The diffable is an acronym of different abilities namely, humans with different abilities. The Indonesian State of Indonesia guarantees the life of every citizen, including persons with disabilities who have the same legal and human rights positions (Indonesia, 2016). Every diffable person has the same rights and opportunities in all aspects of life and livelihood and also deserves accessibility in the context of his independence (Tarsidi, 2008). Fulfillment of convenience requirements applied universal design principles that can be used for special care. These design provisions must address various needs and insights for persons (universal design) with disabilities, children, struggles, and pregnant women (Damayanti, 2015)

\subsection{Horizontal Space Relations}

\subsubsection{Door}

The door is part of the building or space to get in and out. The door has been analysed is the main entrance to the classroom. Based on the standard, all buildings have main doors width that meets the requirements $>90 \mathrm{~cm}$ (Indonesian, 2017) and (Sukamto \& Hetyorini, 2013), see figure 2.

According to the standard, the direction of the opening of the main door of a building, it is required that the main door must be able to be opened in the
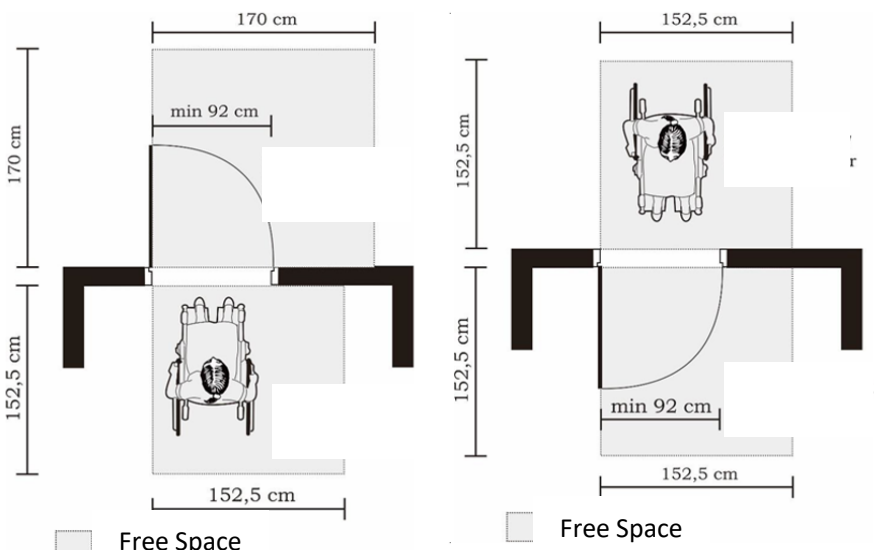

Figure 2. Door Standard

(Minister Regulation PUPR No.14, 2017) direction of the exit for the sake of security, an emergency can occur (see table 1), such is:

1. In GP, the main door on the 2 nd floor has fulfilled the requirements of the openings that can be opened in and out, but the west door is still inward-only. Likewise, the doors in each class and large spaces (hall on the $7^{\text {th }}$ floor) are still made openings only inward.

2. In the Balairung Building, the three main doors are all made openings only inward. Visibility requirements for swing doors are not fulfilled in this building. 
3. In GB the direction of the door opening has not been in the direction of the exit. In the mosque room, the use of the main manual sliding door is also quite difficult during an emergency and have not a visual hole. For the doors of the classes, everything is still opening only inward.

Table 1. Evaluation of The Main Door for Diffable (Analysis, 2018)

\begin{tabular}{|c|c|c|c|c|c|c|c|c|c|c|}
\hline \multirow[b]{2}{*}{ No } & \multirow[b]{2}{*}{ Buildings } & \multirow[b]{2}{*}{ Type } & \multicolumn{2}{|c|}{ Width } & \multicolumn{2}{|c|}{ Free area of Outside } & \multicolumn{2}{|c|}{ Direction } & \multicolumn{2}{|c|}{ Visibility } \\
\hline & & & $\begin{array}{l}\text { Standard } \\
(\mathbf{c m})\end{array}$ & $\begin{array}{c}\text { Existing } \\
\text { (cm) }\end{array}$ & $\begin{array}{c}\text { Standard } \\
(\mathrm{cm})\end{array}$ & $\begin{array}{c}\text { Existing } \\
\text { (cm) }\end{array}$ & Standard & Existing & $\begin{array}{l}\text { Min } \\
(\mathbf{c m})\end{array}$ & $\begin{array}{l}\text { Exist } \\
(\mathrm{cm})\end{array}$ \\
\hline \multirow{4}{*}{1} & \multicolumn{10}{|l|}{ Gedung Pusat (GP) } \\
\hline & a. South door & Glass & $>90$ & 209 & $170 \times 170$ & $682 \times 244$ & outside & In-outside & $<75$ & 0 \\
\hline & b. West door & Iron & $>90$ & 155 & $170 \times 170$ & free & outside & inside & $<75$ & 75 \\
\hline & c. Door Class & Allum & $>90$ & 140 & $170 \times 170$ & free & outside & inside & $<75$ & 10 \\
\hline \multirow{4}{*}{2} & \multicolumn{10}{|l|}{ Gedung Balairung } \\
\hline & a. South door & Wood & $>90$ & 169 & $170 \times 170$ & $172 \times 104$ & outside & inside & $<75$ & None \\
\hline & b. Center door & Wood & $>90$ & 217 & $170 \times 170$ & $643 \times 231$ & outside & inside & $<75$ & None \\
\hline & c. North door & Wood & $>90$ & 169 & $170 \times 170$ & $172 \times 104$ & outside & inside & $<75$ & None \\
\hline \multirow{5}{*}{3} & \multicolumn{10}{|l|}{ Gedung Guru (GB) } \\
\hline & a. South door & Iron & $>90$ & 320 & $170 \times 170$ & free & outside & $\begin{array}{l}\text { sliding } \\
\text { door }\end{array}$ & $<75$ & 4 \\
\hline & b. Mosque door & Wood & $>90$ & 330 & $170 \times 170$ & $150 \times 600$ & outside & inside & $<75$ & None \\
\hline & c. North door & Iron & $>90$ & 320 & $170 \times 170$ & $600 \times 150$ & outside & $\begin{array}{l}\text { sliding } \\
\text { door }\end{array}$ & $<75$ & 4 \\
\hline & d. Door class & Wood & $>90$ & 150 & $170 \times 170$ & bebasx 230 & outside & inside & $<75$ & None \\
\hline \multirow{2}{*}{4} & \multicolumn{10}{|l|}{ Gedung Utama (GU) } \\
\hline & Door Class & Wood & $>90$ & 162 & $170 \times 170$ & free $x 287$ & outside & inside & $<75$ & 100 \\
\hline \multirow[t]{5}{*}{5} & \multicolumn{10}{|c|}{ Pasca Sarjana \& Perpustakaan } \\
\hline & a. $1^{\text {st }}$ south door & Glass & $>90$ & 160 & $170 \times 170$ & $245 \times 213$ & outside & In-out & $<75$ & 0 \\
\hline & b. $2^{\text {nd }}$ south door & Glass & $>90$ & 200 & $170 \times 170$ & $208 \times 215$ & outside & In-out & $<75$ & 0 \\
\hline & c. East door & Glass & $>90$ & 208 & $170 \times 170$ & $208 \times 190$ & outside & In-out & $<75$ & 0 \\
\hline & d. Door class & Glass & $>90$ & 160 & $170 \times 170$ & freex235 & outside & inside & $<75$ & 10 \\
\hline
\end{tabular}

4. In GU, all the class door width requirements, but all openings are still inward, the glass hole on the door is also available, but the height is higher than $75 \mathrm{~cm}$ (see figure 3).

5. At the main door in the GPs has the appropriate width and direction of openings that can be opened both inward and outward, but for the classrooms, they still have the inward-only doors. All doors are made with the glass material, so visuality-wise, it's pretty decent.
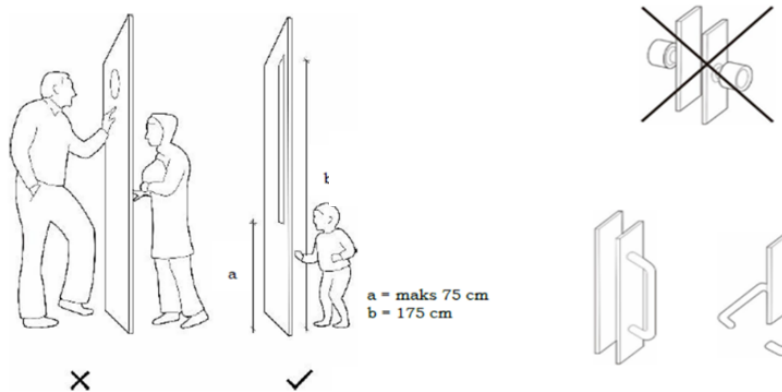

Figure 3 The Standard visibility \& handle of Door (Minister Regulation PUPR No.14, 2017)

In accordance with the use of doors for persons with disabilities, the minimum width of the door is $80 \mathrm{~cm}$, therefore wheelchair users can use it. For wheelchair users, there must be free maneuvering in front and back of the door in a $152 \times 152 \mathrm{~cm}$ wide room. Furthermore, the shape of the handle is friendly for people 
with disabilities and the height of the visual hole should not be more than $75 \mathrm{~cm}$. The results of the study show the various conditions of each building as follows (see table 2):

1. In all buildings, none of lavatory have wide door openings $>80 \mathrm{~cm}$, this has resulted in wheelchair users currently unable to use.

2. From the requirements for the provision of free space in front of the lavatory door, then in all buildings do not have free space to rotate their seats.

3. Requirements for providing visual holes for lavatory doors, only those in the GP and GPs already complied to these conditions.

Table 2. Evaluation of the Lavatory Door for Diffable (Analysis, 2018)

\begin{tabular}{|c|c|c|c|c|c|c|c|c|c|}
\hline \multirow[b]{2}{*}{ No } & \multirow{2}{*}{$\begin{array}{l}\text { Building } \\
\text { Name }\end{array}$} & \multicolumn{2}{|c|}{ Width of Door } & \multicolumn{2}{|c|}{ Free Space } & \multicolumn{2}{|c|}{ Shape of Handle } & \multicolumn{2}{|c|}{ Glass in Swing Door } \\
\hline & & $\begin{array}{l}\text { Standard } \\
\text { (cm) }\end{array}$ & $\begin{array}{l}\text { Exiting } \\
(\mathrm{cm})\end{array}$ & $\begin{array}{l}\text { Standard } \\
\text { (cm) }\end{array}$ & $\begin{array}{c}\text { Exiting } \\
\text { (cm) }\end{array}$ & Standard & Existing & $\begin{array}{l}\text { Standard } \\
(\mathbf{c m})\end{array}$ & $\begin{array}{c}\text { Exiting } \\
(\mathrm{cm})\end{array}$ \\
\hline 1 & GP & 90 & 68 & $152 \times 152$ & $123 \times$ free & Easy & difficult & 75 & 73 \\
\hline 2 & Balairung & 90 & 79 & $152 \times 152$ & $100 \times 111$ & Easy & difficult & 75 & None \\
\hline 3 & GB & 90 & 70 & $152 \times 152$ & $119 \times 177$ & Easy & difficult & 75 & 164 \\
\hline 4 & GU & 90 & 75 & $152 \times 152$ & $83 \times 150$ & Easy & difficult & 75 & 169 \\
\hline 5 & GPs & 90 & 68 & $152 \times 152$ & $115 \times 60$ & Easy & difficult & 75 & 10 \\
\hline
\end{tabular}

\subsubsection{Verandah}

Verandah is a circulation path outside the building which is not limited by walls or limited to at most 1 (one) side of the wall. For the requirements of the verandah associated with the user of disability, it is required to have enough width dimensions for the circulation of wheelchair users and types of surfaces that are not slippery because of the possibility that this corridor can get exposed to rainwater, therefore it can get wet and slippery, (Indonesian, 2017).

There are several buildings that accommodate the verandah, they are in Balairung, GU and GPs. The minimum width of the hallway has been fulfilled for all of these companies, but the type of floor in GU and GPs is still using a slippery floor (see figure 4 and table 3 ).

\subsubsection{Corridor}

Corridor is a circulation path inside or outside of a building which is limited by 2 (two) sides of the wall. The requirements for the corridor are mainly focused in its dimension. Another requirement is the presence

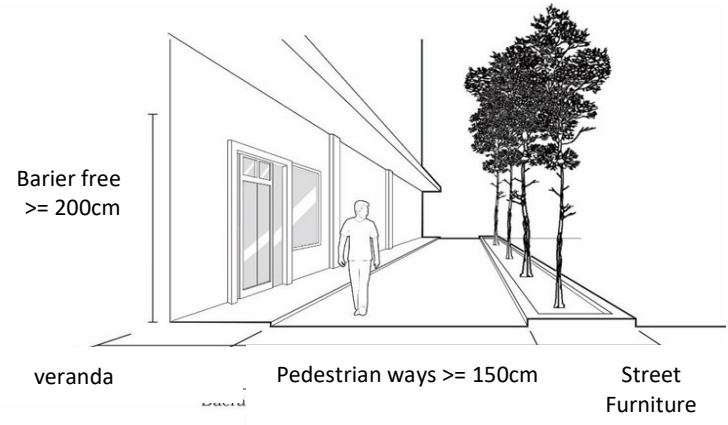

Figure 4. Standard of Verandah

(Minister Reaulation PUPR No.14. 2017)

Table 3. Evaluation of the Breezeway for Diffable (Analysis, 2018)

\begin{tabular}{|c|l|c|c|c|c|}
\hline \multirow{2}{*}{ No } & \multirow{2}{*}{$\begin{array}{c}\text { Building } \\
\text { Name }\end{array}$} & \multicolumn{2}{|c|}{$\begin{array}{c}\text { Breezeway 2 way } \\
\text { (main) }\end{array}$} & \multicolumn{2}{c|}{ Floor Materials } \\
\cline { 3 - 6 } & & Standard & $\begin{array}{c}\text { Exiting } \\
\text { (cm) }\end{array}$ & Standard & Existing \\
\hline \hline 1 & GP & 140 & - & not slippery & None \\
\hline 2 & Balairung & 140 & 283 & not slippery & None \\
\hline 3 & GB & 140 & - & not slippery & None \\
\hline 4 & GU & 140 & 287 & not slippery & slippery \\
\hline 5 & GPs & 140 & 167 & not slippery & slippery \\
\hline
\end{tabular}

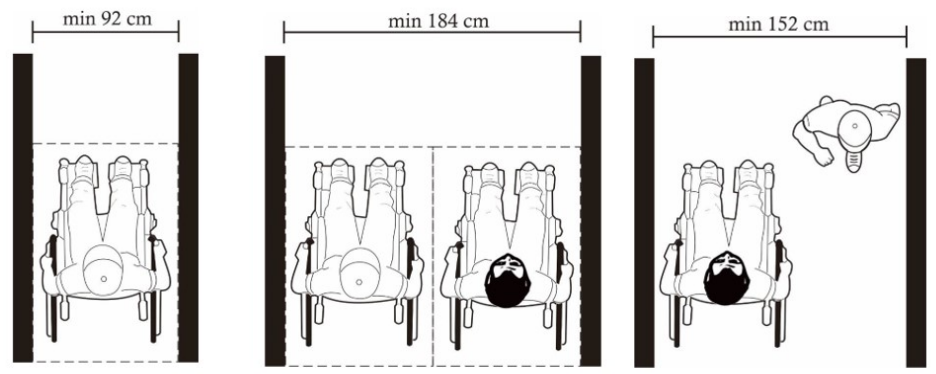

Figure 5. Standard of Corridor (Minister Regulation PUPR No.14, 2017) 
of interference that can reduce and interfere with circulation in the dusty corridor, therefore the chair user cannot use it (see figure 5). Of the five buildings that have been researched, $\mathrm{GU}$ is one of the buildings that have no corridors. It only has a hallway. The GP, Balairung, GB and GPs are having a 2-way corridor that has dimensions of more than $184 \mathrm{~cm}$, therefore wheelchair users can easily and independently use (see table 5). Especially for GPs, there are many chairs in the corridor, thus reducing the width of the corridor width, it is not enough to circulate wheelchair users in two directions.

Table 5. Evaluation the width of Corridor for Diffable (Analysis, 2018)

\begin{tabular}{|c|l|c|c|c|c|c|c|}
\hline \multirow{2}{*}{ No } & \multirow{2}{*}{$\begin{array}{c}\text { Building } \\
\text { Name }\end{array}$} & \multicolumn{2}{|c|}{ Corridor $\mathbf{2}$ way (main) } & \multicolumn{2}{c|}{$\begin{array}{c}\text { Corridor 1 way } \\
\text { (secondary) }\end{array}$} & \multicolumn{2}{|c|}{ Interrupted by Circulation } \\
\cline { 3 - 8 } & & $\begin{array}{c}\text { Standard } \\
(\mathbf{c m})\end{array}$ & $\begin{array}{c}\text { Existing } \\
(\mathbf{c m})\end{array}$ & $\begin{array}{c}\text { Standard } \\
\mathbf{( c m )}\end{array}$ & $\begin{array}{c}\text { Existing } \\
(\mathbf{c m})\end{array}$ & Standard & $\begin{array}{c}\text { Standard } \\
\text { (cm) }\end{array}$ \\
\hline \hline 1 & GP & 184 & 786 & 94 & None & None & None \\
\hline 2 & Balairung & 184 & 235 & 94 & None & None & None \\
\hline 3 & GB & 184 & 210 & 94 & None & None & None \\
\hline 4 & GU & 184 & None & 94 & None & None & None \\
\hline 5 & GPS & 184 & 235 & 94 & None & None & Chairs \\
\hline
\end{tabular}

\subsection{Vertical relationship between floors}

\subsubsection{Stairs}

Stairs is a manual vertical transportation for pedestrians that is designed by considering the slope, footing size, and height of the stairs that are suitable, therefore it is comfortable and safe to use by all users, (Indonesian, 2017). Stair requirements are in the dimensions of height and width of stairs, handrail height and safe stair-shape for blind people and other users. Stair
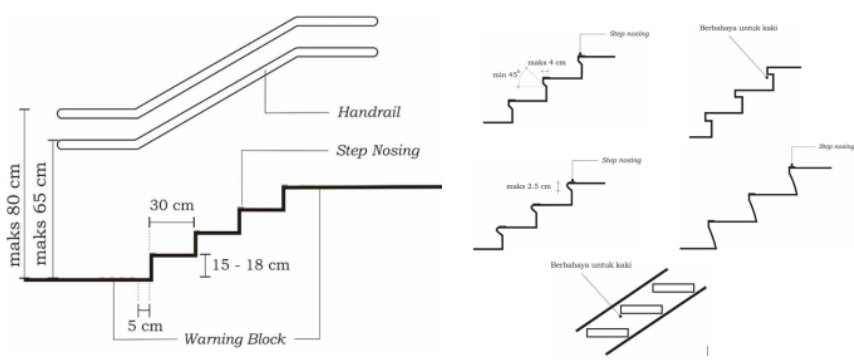

Figure 6. Standard of Stairs

(Minister Regulation PUPR No.14, 2017) dimensions are required to be a maximum of $18 \mathrm{~cm}$, this requirement has been met for all stairs in GP. Likewise, the width of the stairs, is also been more than $30 \mathrm{~cm}$. From the aspect of providing handrail, everything is available, except in the main staircase in front.

In Balairung, all the stairs have dimensions of more than $18 \mathrm{~cm}$, even on the main staircase in the middle has a dimension of $20-21 \mathrm{~cm}$, this is certainly very difficult for people with visual impairments, and becomes very heavy for normal users. This extreme dimension is very dangerous when going downstair because it has a very steep slope angle, especially if someone has to use it during an emergency. Stair width dimensions have been fulfilled, except for the main stairs where the dimensions are only $28-29 \mathrm{~cm}$, this is certainly very dangerous for even normal users, because it makes the angle even steeper. As seen for the shape of the stairs, it is safe enough, although there is a slight slope on the steps, this slope will certainly reduce the dimensions of the stair width when used when going downstair.

The dimension height of GB stairs on the side doors are more than $18 \mathrm{~cm}$, except for the middle steps to enter the mosque. This will certainly be a big hassle for normal users, as well as making it difficult for people with disabilities (blind people and crutch users). The height of the stairs will be relieved for the user, only this stair can use to access all floor (5th floor 
without elevator). The dimensions of the stairs also have not met the requirements and dimensions of less than $30 \mathrm{~cm}$. The handrail is all available, but the height is still too high all above $80 \mathrm{~cm}$. The shape of the stairs is relatively safe with a slight slope, but if it is associated with a less width dimension, then at the time of descending it will certainly be more space for the foot. For the GU Building, it has excessive stair height that makes the users get tired quickly. For the width dimension, it meets the requirements. The provision of hand towels is available, but the height still exceeds $80 \mathrm{~cm}$. the shape of the stairs is safe, where the stairs are vertical upright. For stairs in GPs on the south staircase and stairs in the GPs are more than the standard. The height of the handrail on all stairs is also too high, more than $80 \mathrm{~cm}$, while the shape of the steps is quite safe considering the width of the steps is more than $30 \mathrm{~cm}$, not on the east staircase.

Table 6.Evaluation of Stairs for Diffable (Analysis, 2018)

\begin{tabular}{|c|c|c|c|c|c|c|c|c|c|c|}
\hline \multirow[b]{2}{*}{ No } & \multirow[b]{2}{*}{ Building Name } & \multirow[b]{2}{*}{$\begin{array}{c}\text { Width } \\
\text { (cm) }\end{array}$} & \multicolumn{2}{|c|}{ Antrade } & \multicolumn{2}{|c|}{ Optrode } & \multicolumn{2}{|c|}{$\begin{array}{l}\text { Height of } \\
\text { Handrail }\end{array}$} & \multicolumn{2}{|c|}{ Shape of Antrade } \\
\hline & & & $\begin{array}{l}\text { Standard } \\
\text { (cm) }\end{array}$ & $\begin{array}{l}\text { Exist } \\
(\mathrm{cm})\end{array}$ & $\begin{array}{l}\text { Standard } \\
\text { (cm) }\end{array}$ & $\begin{array}{l}\text { Exist } \\
(\mathrm{cm})\end{array}$ & $\begin{array}{c}\text { Stand } \\
\text { ard } \\
(\mathrm{cm})\end{array}$ & $\begin{array}{l}\text { Exist } \\
(\mathrm{cm})\end{array}$ & $\begin{array}{c}\text { Standar } \\
\text { d } \\
\end{array}$ & $\begin{array}{l}\text { Standard } \\
\text { (cm) }\end{array}$ \\
\hline 1 & \multicolumn{10}{|l|}{ GP } \\
\hline$a$ & Main Stair & 682 & $15-18$ & 18 & $\ldots>30$ & 31 & $65-80$ & None & Save & Save \\
\hline$b$ & East Stairs & 162 & $15-18$ & 18 & $\ldots>30$ & 34 & $65-80$ & $87-96$ & Save & Save \\
\hline c & West Stairs & 200 & $15-18$ & 18 & $\ldots>30$ & 30 & $65-80$ & 100 & Save & Save \\
\hline 2 & \multicolumn{10}{|l|}{ Balairung } \\
\hline a & South Stairs & 175 & $15-18$ & 19 & $\ldots>30$ & 33 & $65-80$ & 110 & Save & Save \\
\hline$b$ & Center Stairs & 310 & $15-18$ & $20-21$ & $\ldots>30$ & $28-29$ & $65-80$ & 95 & Save & Dangerous \\
\hline c & North Stairs & 175 & $15-18$ & 19 & $\ldots>30$ & 33 & $65-80$ & 110 & Save & Save \\
\hline 3 & \multicolumn{10}{|l|}{$\mathrm{GB}$} \\
\hline a & South Stairs & 165 & $15-18$ & 19 & $\ldots>30$ & 29 & $65-80$ & 109 & Save & Save \\
\hline$b$ & Mosque Stairs & 370 & $15-18$ & 17 & $\ldots>30$ & 28,5 & $65-80$ & 84 & Save & Save \\
\hline c & North Stairs & 165 & $15-18$ & 19 & $\ldots>30$ & 29 & $65-80$ & 109 & Save & Save \\
\hline 4 & GU & & & & & & & & & \\
\hline a & Front Stairs & 118 & $15-18$ & 20,5 & $\ldots>30$ & 30 & $65-80$ & 118 & Save & Save \\
\hline $\mathrm{b}$ & Back Stairs & 175 & $15-18$ & 20 & $\ldots>30$ & 31 & $65-80$ & 111 & Save & Save \\
\hline 5 & \multicolumn{10}{|l|}{ GPs } \\
\hline a & $1^{\text {st }}$ South Stairs & 139 & $15-18$ & 20 & $\ldots>30$ & 30,5 & $65-80$ & 91 & Save & Save \\
\hline$b$ & $2^{\text {nd }}$ South Stairs & 140 & $15-18$ & 15 & $\ldots>30$ & 30 & $65-80$ & 94 & Save & Dangerous \\
\hline c & East Stairs & 208 & $15-18$ & 17 & $\ldots>30$ & 29 & $65-80$ & 84 & Save & Save \\
\hline $\mathrm{e}$ & $1^{\text {st }}$ East Stairs & 142 & $15-18$ & 19 & $\ldots>30$ & 30 & $65-80$ & 91 & Save & Save \\
\hline $\mathrm{E}$ & $2^{\text {nd }}$ East Stairs & 140 & $15-18$ & 18 & $\ldots>30$ & 30 & $65-80$ & 90 & Save & Save \\
\hline
\end{tabular}

\subsubsection{Ramp}

The use of the ramp for the pedestrian is practically non-existent for all buildings, therefore every difference in floor height will be a major obstacle for wheelchair users (Indonesian, 2017).

In GP, it is necessary to have a ramp at the main entrance from the west, because the floor difference is around $30 \mathrm{~cm}$. Problems in Balairung are also similar, where the ramp is also provided for motorized vehicles with very high slopes. Access for persons with disabilities makes it impossible to enter the main floor (3rd floor) from any entrance. 
In GU building, the ramp is not available for access from the road to the ground floor of the building, it requires the addition of a ramp in this building, therefore users with disabilities can access the elevator and move to all floors. For GPs there is already a ramp outside with a gentle slope, so wheelchair users can access the elevator for distribution to all rooms in the GPs. The library building does not have the ramp, so wheelchair users cannot access the main floor (2nd floor).

Table 7. Evaluation of the Ramp for Diffable (Analysis, 2018)

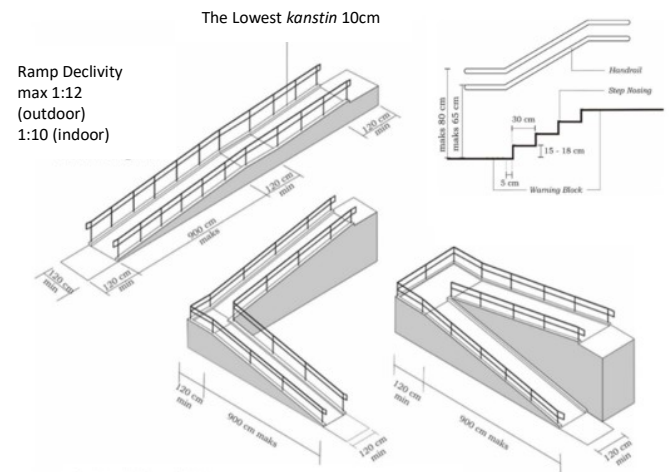

Figure 7. Standard of Ramp (Minister Regulation PUPR No.14, 2017)

\begin{tabular}{|c|c|c|c|c|c|c|c|c|c|c|}
\hline \multirow[b]{2}{*}{ No } & \multirow[b]{2}{*}{ Building Name } & \multirow[b]{2}{*}{ Function } & \multirow[b]{2}{*}{$\begin{array}{c}\text { Lengt } \\
h\end{array}$} & \multirow[b]{2}{*}{ Height } & \multicolumn{2}{|c|}{ Slope } & \multicolumn{2}{|c|}{ Width } & \multicolumn{2}{|c|}{ Height of Handrail } \\
\hline & & & & & $\begin{array}{c}\text { Standard } \\
\left.(\ldots .)^{0}\right)\end{array}$ & $\begin{array}{c}\text { Exiting } \\
\left.(\ldots .)^{0}\right)\end{array}$ & $\begin{array}{l}\text { Standar } \\
\text { d (cm) }\end{array}$ & $\begin{array}{l}\text { Existin } \\
\text { g (cm) }\end{array}$ & $\begin{array}{c}\text { Standa } \\
\text { rd } \\
(\mathrm{cm})\end{array}$ & $\begin{array}{c}\text { Existing } \\
(\mathrm{cm})\end{array}$ \\
\hline \multirow[t]{4}{*}{1} & GP & & & & & & & & & \\
\hline & Ramp for car & Car & 1870 & 350 & $<20$ & & $95-120$ & 407 & $65-80$ & 100 \\
\hline & Ram for bicycle & $\begin{array}{c}\text { Motorcycl } \\
\mathrm{e}\end{array}$ & 921 & 280 & $<20$ & & $95-120$ & 126 & $65-80$ & 81 \\
\hline & Ramp for Pedestrian & People & None & None & 3 & None & $95-120$ & None & $65-80$ & None \\
\hline \multirow[t]{4}{*}{2} & Balairung & & & & & & & & & \\
\hline & Ram for car (front) & Mobil & 19 & 4,02 & $<20$ & 12,9 & $95-120$ & 332 & $65-80$ & 83 \\
\hline & Ram for car (back) & $\begin{array}{c}\text { Car/Motor } \\
\text { cycle }\end{array}$ & 2000 & 350 & $<20$ & None & $95-120$ & 400 & $65-80$ & 12 \\
\hline & Ram for Pedestrian & People & None & None & 3 & None & $95-120$ & None & $65-80$ & None \\
\hline 3 & GB & People & None & None & 5 & None & $95-120$ & None & $65-80$ & None \\
\hline 4 & GU & People & None & None & 5 & None & $95-120$ & None & $65-80$ & None \\
\hline 5 & GPs & People & 220 & 50 & 5 & None & $95-120$ & None & $65-80$ & None \\
\hline
\end{tabular}

\subsubsection{Lift}

Lift is an electrical mechanical device to assist in the vertical plane movement inside the building. The provision of elevators is used to access vertical transportation with easily and effectively. Problems regarding these lifts are found in the GP building because the lift only works from floors 2-7, so to access the building from the $1^{\text {st }}$ floor must go up the stairs. For the Balairung building that only consists 3 floors, it is not required to have an elevator, but the current condition there is a big obstacle for wheelchair users to be able to access the main floor.

Table 8. Evaluation Elevator for Diffable (Analysis, 2018)

\begin{tabular}{|c|l|c|c||c|c|c|c|c|c|}
\hline \multirow{2}{*}{ No } & \multirow{2}{*}{$\begin{array}{c}\text { Building } \\
\text { Name }\end{array}$} & \multicolumn{2}{|c|}{$\begin{array}{c}\text { The dimension } \\
\text { of Car Lift }\end{array}$} & $\begin{array}{c}\text { Number of Floor } \\
\text { Services }\end{array}$ & \multicolumn{2}{c|}{ Width of Door } & \multicolumn{2}{c|}{ Floor Services } \\
\cline { 3 - 10 } & & Length & Width & $\begin{array}{c}\text { Standard } \\
\text { (Floor) }\end{array}$ & $\begin{array}{c}\text { Existing } \\
\text { (floor) }\end{array}$ & $\begin{array}{c}\text { Standard } \\
\text { (cm) }\end{array}$ & $\begin{array}{c}\text { Existing } \\
\text { (cm) }\end{array}$ & Length & Width \\
\hline \hline 1 & GP & 160 & 150 & $>5$ & 7 & $\ldots \ldots .>110$ & 90 & All & $2-7$ \\
\hline 2 & Balairung & None & None & $>5$ & None & $\ldots \ldots>110$ & None & All & None \\
\hline 3 & GB & None & None & $>5$ & None & $\ldots \ldots .>110$ & $\times$ & All & None \\
\hline 4 & GU & 160 & 150 & $>5$ & 6 & $\ldots . .>110$ & 90 & All & $1-6$ \\
\hline 5 & GPS & 160 & 150 & $>5$ & 5 & $\ldots . .>110$ & 90 & All & $1-5$ \\
\hline \hline
\end{tabular}


GB is a 5-story building with all its regular functions, the height of stairs and limited width of stairs making access to the upper floors very tiring. An alternative to adding a lift is needed for this building because its function can be extended to the PKM building. For elevators at $\mathrm{GU}$, it is quite ideal with service to all floors. The problems are in the library building which is directly connected to the GPs, even though the two building have been connected directly, but it turns out that all the height of the main hall is not the same, it even has a level difference of around $150 \mathrm{~cm}$.

\subsection{Requirements of completeness of the facilities and infrastructure}

\subsubsection{Toilet}

From the results of the study, the availability of toilets in all buildings was not planned for diffabled people. The use of closed seatings is still not available, except in the Balairung Building and GU. The dimensions of the toilet room are all still not sufficient for the use of wheelchair users, so it requires careful designing because it requires some changes to the layout of the bathroom space.

Table 9 Evaluation of Toilets for Difabled (Analysis, 2018)

\begin{tabular}{|c|c|c|c|c|c|c|c|c|c|}
\hline \multirow[b]{2}{*}{ No } & \multirow[b]{2}{*}{$\begin{array}{c}\text { Building } \\
\text { Name }\end{array}$} & \multicolumn{2}{|c|}{ Type of Toilet } & \multicolumn{2}{|c|}{ Width of Cubical } & \multicolumn{2}{|c|}{ Door Closer } & \multicolumn{2}{|c|}{ Kick Door Plate } \\
\hline & & Standard & Existing & $\begin{array}{l}\text { Standard } \\
(\mathbf{c m})\end{array}$ & $\begin{array}{c}\text { Existing } \\
\text { (cm) }\end{array}$ & Standard & $\begin{array}{c}\text { Existing } \\
\text { (cm) }\end{array}$ & Standard & Standard \\
\hline 1 & GP & Sitting & Squat & $152,5 \times 227,5$ & $126 \times 158$ & Exist & None & Exist & None \\
\hline 2 & Balairung & Sitting & Sitting & $152,5 \times 227,5$ & $103 \times 134$ & Exist & None & Exist & None \\
\hline 3 & GB & Sitting & Squat & $152,5 \times 227,5$ & $119 \times 125$ & Exist & None & Exist & None \\
\hline 4 & GU & Sitting & Squat & $152,5 \times 227,5$ & $165 \times 240$ & Exist & None & Exist & None \\
\hline a & GPs & Sitting & Squat & $152,5 \times 227,5$ & $186 \times 190$ & Exist & None & Exist & None \\
\hline
\end{tabular}

\subsubsection{Handwashing}

The provision of new handwashing facilities is available in GPs and Balairung, but for GP wheelchair users can use it because of the design of a hand sink that has not allowed the foot to come under the sink, and the dimensions of space are very limited. For handwashing in the Balairung has been qualified to be used by wheelchair users.

Table 10. Evaluation of Handwashing Function for

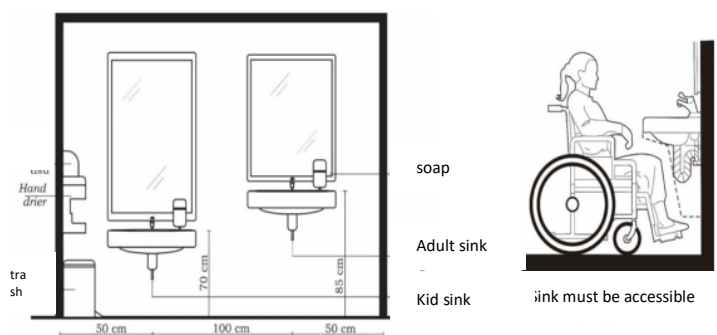

Figure 8. Standard of Handwashing (Minister Regulation PUPR No.14, 2017) Diffable

\begin{tabular}{|c|c|c|c|c|c|c|c|c|c|c|c|}
\hline \multirow[b]{2}{*}{ No } & \multirow[b]{2}{*}{$\begin{array}{l}\text { Building } \\
\text { Name }\end{array}$} & \multicolumn{2}{|c|}{ Width } & \multicolumn{2}{|c|}{ Height } & \multicolumn{2}{|c|}{$\begin{array}{c}\text { Deployment of } \\
\text { wheelchair users }\end{array}$} & \multicolumn{2}{|c|}{ Handrail } & \multicolumn{2}{|c|}{$\begin{array}{c}\text { Circulation dan Free } \\
\text { Area }\end{array}$} \\
\hline & & $\begin{array}{l}\text { Standard } \\
\quad(\mathrm{cm})\end{array}$ & $\begin{array}{c}\text { Existing } \\
(\mathrm{cm})\end{array}$ & $\begin{array}{l}\text { Standa } \\
\text { rd (cm) }\end{array}$ & $\begin{array}{l}\text { Existing } \\
\quad(\mathrm{cm})\end{array}$ & $\begin{array}{l}\text { Stand } \\
\text { ard }\end{array}$ & $\begin{array}{l}\text { Existin } \\
\mathbf{g}\end{array}$ & $\begin{array}{c}\text { Standa } \\
\text { rd } \\
(\mathrm{cm}) \\
\end{array}$ & $\begin{array}{c}\text { Standa } \\
\text { rd } \\
(\mathrm{cm}) \\
\end{array}$ & $\begin{array}{c}\text { Existing } \\
\text { (cm) }\end{array}$ & $\begin{array}{l}\text { Standard } \\
\text { (cm) }\end{array}$ \\
\hline 1 & GP &..$>60$ & 97 & 75 & 92 & Exist & Can't & Exist & None & 120 & 140 \\
\hline 2 & Balairung &..$>60$ & 99 & 75 & 80 & Exist & Can & Exist & None & 120 & 88 \\
\hline 3 & GB &..$>60$ & None & 75 & None & Exist & None & Exist & None & 120 & None \\
\hline 4 & GU &..$>60$ & None & 75 & None & Exist & None & Exist & None & 120 & None \\
\hline 5 & GPs &..$>60$ & None & 75 & None & Exist & None & Exist & None & 120 & None \\
\hline
\end{tabular}




\subsubsection{Urinal}

The provision of new urinal facilities available for GP, Balairung, and GB. The height of the urinal has met the standard, but all of them have no boundary chamber (except GB). For the needs of people with disabilities, all of those above have not provided handrail.

Table 11.Evaluation the Urinal for Difabled

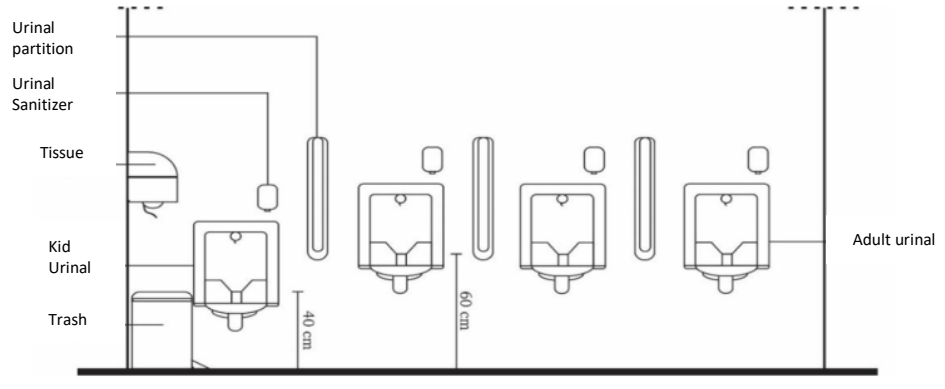

Figure 9. Standard of Urinal (Minister Regulation PUPR No.14, 2017)

\begin{tabular}{|c|c|c|c|c|c|c|c|c|c|c|}
\hline \multirow[b]{2}{*}{ No } & \multirow[b]{2}{*}{ Building Name } & \multirow{2}{*}{$\begin{array}{c}\text { Existed } \\
\text { of } \\
\text { Partition }\end{array}$} & \multicolumn{2}{|c|}{ Width } & \multicolumn{2}{|c|}{ Height } & \multicolumn{2}{|c|}{$\begin{array}{c}\text { Full Height of } \\
\text { Urinal }\end{array}$} & \multicolumn{2}{|c|}{ Handrail } \\
\hline & & & $\begin{array}{c}\text { Stand } \\
\text { ard } \\
(\mathrm{cm})\end{array}$ & $\begin{array}{c}\text { Existing } \\
(\mathbf{c m})\end{array}$ & $\begin{array}{c}\text { Standa } \\
\text { rd } \\
(\mathrm{cm})\end{array}$ & $\begin{array}{c}\text { Exiting } \\
(\mathrm{cm})\end{array}$ & $\begin{array}{c}\text { Standa } \\
\text { rd }\end{array}$ & Exiting & $\begin{array}{c}\text { Standa } \\
\text { rd }\end{array}$ & $\begin{array}{l}\text { Existing } \\
\text { (cm) }\end{array}$ \\
\hline 1 & GP & $x$ & $>60$ & 84 & 60 & 60 & Exist & None & Exist & None \\
\hline 2 & Balairung & $\mathrm{x}$ & $>60$ & 89 & 60 & 45 & Exist & None & Exist & None \\
\hline 3 & GB & Exist & $>60$ & 67 & 60 & 52 & Exist & None & Exist & None \\
\hline 4 & GU & $\mathrm{x}$ & $>60$ & None & 60 & None & Exist & None & Exist & None \\
\hline 5 & GPs & $x$ & $>60$ & None & 60 & None & Exist & None & Exist & None \\
\hline
\end{tabular}

\subsubsection{Parking lot}

The building is determined for the termination of vehicles within a certain period of time in the form of a parking lot, parking in a building. The results of research on the existence of this parking lot are as follows: For all buildings, none of them provides special facilities for persons with disabilities, it will make it difficult for visitors to have the facilities that bring the car to go down or ride easily (Indonesian, 2017).

\subsubsection{Comparison between Buildings}
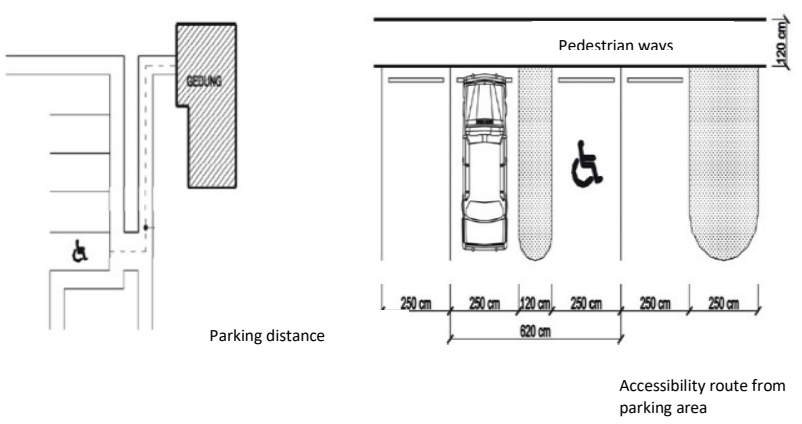

Figure 10. The standard of Parking Lots (Minister Regulation PUPR No.14, 2017)

From all result of the analysis, we can compare from each building as see below:

Table 12. Compare of constraint between Buildings

\begin{tabular}{|c|c|c|c|c|c|c|c|c|c|c|c|c|c|c|c|}
\hline No & Buiding & 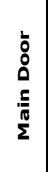 & $\begin{array}{l}\swarrow \\
\vdots \\
0 \\
\vdots \\
0 \\
0 \\
0 \\
0\end{array}$ & 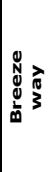 & 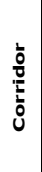 & $\frac{n}{n}$ & $\vec{E}$ & $\stackrel{5}{\Xi}$ & $\begin{array}{l}\vec{u} \\
\overline{0} \\
\vdash\end{array}$ & 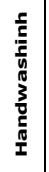 & $\begin{array}{l}\bar{\pi} \\
\overline{5} \\
\overline{5}\end{array}$ & $\begin{array}{l}\overrightarrow{0} \\
0 \\
0 \\
\frac{E}{2} \\
\frac{5}{6} \\
0\end{array}$ & $\begin{array}{c}\text { Summary } \\
\text { of } \\
\text { obstacle }\end{array}$ & Score & Ranking \\
\hline & & $15 \%$ & $15 \%$ & $5 \%$ & $5 \%$ & $5 \%$ & $10 \%$ & $20 \%$ & $10 \%$ & $5 \%$ & $5 \%$ & $5 \%$ & & & \\
\hline 1 & GP & 2 & 3 & 0 & 0 & 3 & 4 & 2 & 4 & 4 & 2 & 4 & 28 & 2,60 & IV \\
\hline 2 & Balairung & 8 & 4 & 0 & 0 & 8 & 5 & 3 & 3 & 3 & 2 & 4 & 40 & 4,05 & I \\
\hline 3 & GB & 6 & 4 & 0 & 0 & 8 & 3 & 2 & 4 & 5 & 2 & 4 & 38 & 3,55 & II \\
\hline 4 & GU & 2 & 4 & 1 & 0 & 4 & 3 & 1 & 3 & 5 & 4 & 4 & 31 & 2,60 & IV \\
\hline 5 & GPS & 1 & 3 & 1 & 1 & 10 & 3 & 2 & 4 & 5 & 4 & 4 & 38 & 2,95 & III \\
\hline
\end{tabular}

Figure 11. Rank of priority to retrofit

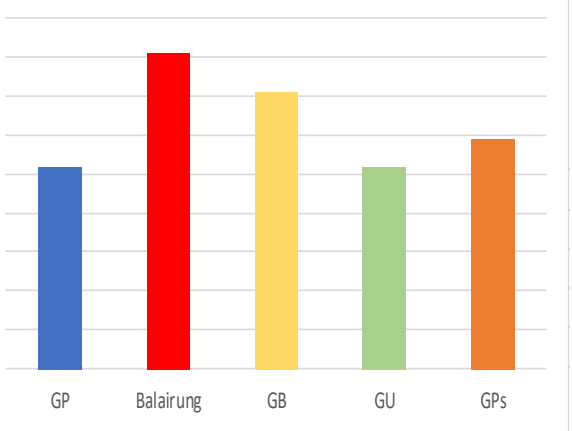




\section{Conclusion and Suggestion}

Conclusion:

1. The biggest problem with accessibility is Balairung Building with 4,05 points, the second score is GB with 3,55 points, the third score is GPs with 2,95 points.

2. In GP, the wheelchair users cannot access public spaces because the elevator is not available to be accessed from the ground floor. Accessibility problems also occur in the GB and Balairung Building which does not have an elevator.

3. Provision of toilets for persons with disabilities is not yet available in all existing buildings. The main obstacle is the insufficient dimensions of the toilet space and the door width are less than $80 \mathrm{~cm}$. The provision of a hand sink is appropriate for the Balairung Building, but for GP it has not met the standards. This facility is not yet available in other buildings.

4. Dimensional conditions of the antrade and optrade of stairs in almost all buildings are very limited so that in addition to being difficult and defeating to go through, it is also very dangerous to go down the stairs, especially in emergency situations. The most dangerous condition is on the main staircase of the Balairung building.

5. The direction of the opening of the main doors and classes are all still made with the direction of opening inward-only (except the main door in the GP and GPs), this is very dangerous when an emergency occurs.

Suggestion:

1. Addition of elevators for Balairung and GB to be accessible to all users, including the diffabled people.

2. Need designing in the provision of special toilets for diffabled people in all building.

3. Need to add hand-washing facilities that can be used easily by the diffabled people, except in the Balairung which is already available well.

4. Repair of stair dimensions, especially in the main door of the Balairung to make it more secure and comfortable.

5. Change the direction of the opening the main doors to the outside for all building.

\section{References}

Damayanti, P. A. (2015). SEKOLAH DASAR LUAR BIASA (SDLB) DI KOTA SEMARANG DENGAN PENEKANAN DESAIN UNIVERSAL. Canopy: Journal of Architecture, 4(2), $1-8$.

Harahap, R. . and B., \& Bustanuddin. (2015). PERLINDUNGAN HUKUM TERHADAP PENYANDANG DISABILITAS MENURUT CONVENTION ON THE RIGHTS OF PERSONS WITH DISABILITIES (CRPD). Jurnal Inovatif, VIII(1), 17-29.

Indonesia, P. R. (2016). UNDANG-UNDANG NO.8 TAHUN 2016 TENTANG PENYANDANG DISABILITAS. Jakarta.

Indonesian, M. of P. W. and S. of. (2017). PERSYARATAN KEMUDAHAN BANGUNAN GEDUNG.

Masruroh, F., Mauliani, L., Ayodia, T., \& Menteng, T. (2006). Kajian Arsitektural Taman Yang Mengakomodasi Aksesibilitas Difabel Studi Kasus Taman Tribeca Central Park Mall , Taman Menteng Dan Taman Ayodia.

Sukamto, D., \& Hetyorini. (2013). ANALISIS PENINGKATAN FUNGSI BANGUNAN UMUM MELALUI UPAYA DESAIN ACCESSIBILITY. In Proseding SNST ke-4 Tahun 2013 (Vol. 1945, pp. 9-14).

Tarsidi, D. (2008). AKSISIBILITAS LINGKUNGAN FISIK BAGI PENYANDANG CACAT.

Utomo. (2014). AKSESIBILITAS PENYANDANG DISABILITAS MENEMPUH PENDIDIKAN TINGGI, 1-7. 